\title{
A sportolói identitás és a sport-elköteleződés összefüggései serdülő sportolók körében
}

\author{
Berki Tamás* és Pikó Bettina**
}

Számos nemzetközi kutatás bizonyította a sportolói identitás jelentőségét serdülő sportolóknál, hiszen az közvetve befolyásolhatja testi és szellemi fejlődésüket. Hazánkban a sportolói identitás vizsgálata még gyermekcipőben jár, ezért célunk az volt, hogy feltárjuk a serdülö sportolók identitásának összefüggéseit szociodemográfiai adatokkal, sportolási szokásokkal és a sport-elköteleződés modellel. Összesen 344 középiskolás sportoló vett részt a kutatásunkban, akiknek átlagéletkora 16,6 életév volt. Kérdőives vizsgálatunkhoz a szociodemográfiai adatok és sportolási szokások mellett az ún. Sportolói identitás skálát és az ún. Sport-elköteleződés kérdőívet használtuk. Adataink elemzéséhez kétmintás t-próbát, egyszempontos varianciaanalizist, korrelációt, valamint regresszióanalizist alkalmaztunk. Eredményeinkben azt tapasztaltuk, hogy a sportolói identitás szintje nemenként, tagozatonként, versenyzési szintekként különbözik, és függ a kortól, a sportágban eltöltött idötôl, valamint az edzésmennyiségtöl is. Regressziós elemzésünkből kiderült, hogy a sport iránti elköteleződés nagymértékben magyarázza a sportolói identitást. Személyes befektetések-mennyiség és a Lelkes elköteleződés rendelkeznek a legnagyobb magyarázó erővel a sportolói identitásra. Az Értékes lehetőségek, Törekvés a fejlödésre - közösség, Eröltetett elköteleződés, és a Közösségi támogatás - érzel mi változók szintén szignifikánsan pozitiv magyarázó erővel bírnak a modellben. Érdekes módon a Sportélvezet és a Törekvés a fejlődésre, egyéni, negativ kapcsolatban állnak a sportolói identitással, miközben korábbi tanulmányok rávilágítottak pozitív hatásukra a fizikai aktivitás terén. Eredményeinkböl arra következtethetünk, hogy a magas fokú identitás kialakulása nemcsak belső motiváció eredménye lehet, hanem a közösség, de még a kényszer hatására történő sportolás is erősitheti a sportolói identitást.

Kulcsszavak: sportolói identitás, sport-elköteleződés, serdülők, regresszió

\section{Bevezetés}

A neveléstudomány számára fontos kihívás az identitás fejlődésének nyomon követése, illetve jótékony befolyásolása. Az identitás, vagyis az én-azonosság az egyik legfontosabb pszichikus közvetítő konstrukció az egyén és a társadalom között, mely nagyban segíti a serdülők szocializációját (Pataki, 1982). Kutatások azt mutatják, hogy az identitás formálódását számos tényező befolyásolhatja, mint a barátok (Weiss \& Wood, 2005), a család (Deephouse \& Jaskiewicz, 2013), a zene (Tekman \& Hortacsu, 2002) vagy a sport (Brewer, Van Raalte, \& Linder, 1993). A tanulmányok már számos alkalommal igazolták, hogy a sportnak igen magas szintú jellemformáló hatása van a serdülőkre. A rendszeres testmozgást végző serdülők magasabb önértékeléssel (Baker, Little \& Brownell, 2003), jobb tanulmányi eredményekkel rendelkeznek (Van Dusen et al., 2011), valamint egészségesebbek és védettebbek a különböző egészségkockázati magatartásformáktól (pl. dohányzás, alkoholfogyasztás), mint kevésbé aktív társaik (lásd pl. Mikulán, 2007). A pozitív hatások ellenére a túlzott testmozgás is veszélyeket rejthet. Szabó (2018) szerint a testedzésfüggőség legalább olyan negatív hatásokat hordozhat,

Egyetemi adjunktus, SZTE, Juhász Gyula Pedagógusképző Kar, Testnevelési és Sporttudományi Intézet. e-mail: berkitamas@edu.u-szeged.hu

** Egyetemi tanár, SZTE Általános Orvostudományi Kar, Magatartástudományi Intézet, e-mail: fuzne.piko.bettina@med.u-szeged.hu 
mint az említett rizikófaktorok, és akár evészavarokhoz is vezethet. A felsorolt kutatások azt mutatják, hogy a sport általi nevelés kihat a személyiség valamennyi területére.

A sportolói identitás meghatározó szerepet tölthet be a tanulók sportolási szokásaiban és a sportmotivációban, ami közvetett hatással lehet az egészségmegőrzésre és a testi-szellemi fejlódésre is. A sportolói identitás fogalmát Brewer, Van Raalte és Lindner (1993) vezették be. Szerintük a sportolói identitás „a sportolói szerep egyéni identitásba való beépülésének mértéke" (Brewer et al., 1993; p. 237.). A nemzetközi szakirodalomban a sportolói identitás kutatása igen népszerú, és számos összefüggését tárták fel az elmúlt húsz évben. Úgy tűnik a sportolói identitás kihat a személyiségfejlődésre, a megfelelő egészségmagatartás kialakulására és a motivációkra is. Többek között Martin, Fogarty és Albion (2014) vizsgálatából kiderül, hogy az erőteljesebb sportolói identitással rendelkezők pozitivabb szubjektív jólléttel rendelkeznek, ráadásul ez a jóllét-szint akkor is megmarad, ha a sportoló önként és nem sérülés vagy a kiégés miatt hagyja abba a versenysportot. Egy másik vizsgálat azt hangsúlyozza, hogy minél nagyobb fokú a sportolói identitás, annál többet sportol az illető (Lamont-Mills \& Christensen, 2006), melynek köszönhetően a sportolók magabiztosabbak, és kevésbé érinti őket a kiégés problémája (Burns, Jasinski, Dunn, \& Fletcher, 2012).

A sport általi nevelés szempontjából kiemelt jelentősége van a sportolói identitás és a sportmotiváció kapcsolatának, mely számos kutatás középpontjába került. Wilson és Moun (2008) szerint például a magasabb pszichológiai szükséglet nagyobb fokú identitáshoz vezet. Egy másik tanulmány arról, ír, hogy az öndeterminációs elmélet és az identitás között számos kapcsolat található, hiszen mind a két koncepció a viselkedésre jel lemző elemekre épül (pl. énközpontúság, önszabályozás; Vlachopoulos, Kaperoni, \& Moustaka, 2011). Ezen kutatások szerint a sportolói identitás és az öndetermináció között erős korreláció tapasztalható, ami különösen nagy az identifikált és az integrált szabályozás között (Vlachopoulos et al., 2011; Strachan, Fortier, Perras, \& Lugg, 2013). Ez arra enged következtetni, hogy a sportolói identitás a belső és a külső motivációkból egyaránt merítheti az erejét.

E kutatások alapján úgy látjuk, hogy az identitás és a motiváció közötti kapcsolat nem elhanyagolható, így érdemes tovább vizsgálni. Azonban jelen kutatásunk elméleti alapjait nem a klasszikusnak mondható Öndeterminációs elmélet (Deci \& Ryan, 2000) adta, hanem az ún. Sport-elköteleződés modell. A modellt és a hozzá kapcsolódó skálát Tara Scanlan és munkatársai (1993) alkották meg, melyet a hosszú évek folyamán folyama tosan fejlesztettek, kibővítettek, és 2016-ban újra publikáltak (Scanlan et al., 2016) (1. ábra). 


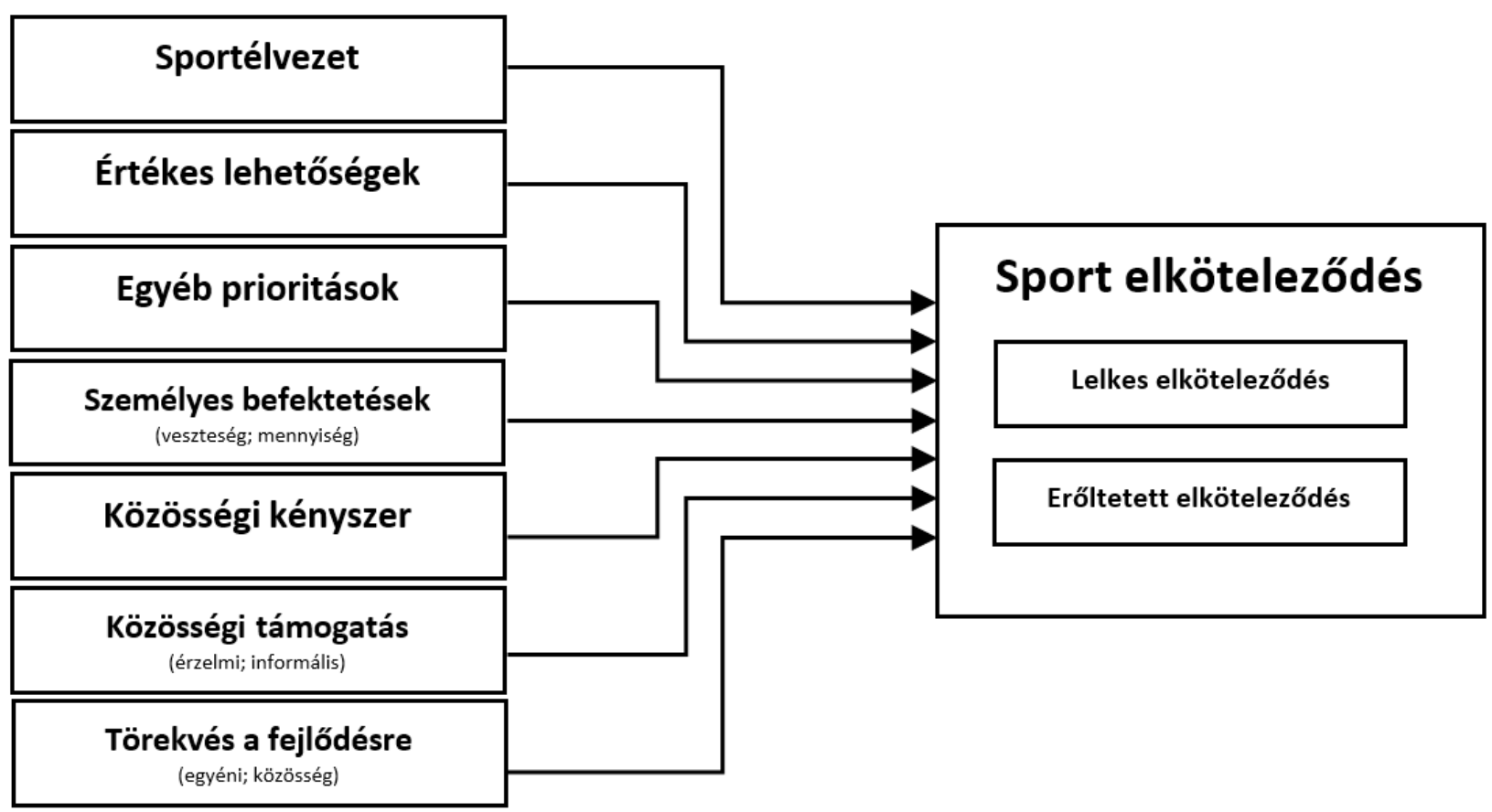

1. ábra A Sport-elköteleződés modell (Forrás: Scanlan et al. 2016.)

A Sport-elköteleződés modell megkülönbözteti a kétféle elköteleződés-típust (lelkes és erőltetett), és annak hét forrását (Sportélvezet, Értékes lehetőségek, Egyéb prioritások, Személyes befektetések, Közösségi támogatás, Közösségi kényszer, Törekvés a fejlődésre). A fogalma szerint a Lelkes elköteleződés „egy olyan pszichológiai állapot, amely a sporttevékenység folytatásához köthető elszántságot és vágyakozást ábrázolja" (Scanlan et al., 2016, p. 213). Az Erőltetett elköteleződés pedig a „sporttevékenység folytatásához köthető kötelezettséget ábrázolja" (Scanlan et al., 2016, p. 213). A Lelkes elköteleződésre jellemző, hogy az egyén saját maga akar részt venni a sporttevékenységben, míg az Erőltetett elköteleződés valamilyen kényszer hatására alakul ki (pl. elvárások). Az elmúlt évek kutatásai számos lehetséges elemet azonosítottak, mint a kétféle sport-elköteleződés típus lehetséges forrásait. Végül hét forrás került be a legújabb modellbe, melyet 10 alskálán keresztül vizsgálnak a kutatók (Scanlan et al., 2016).

A kutatásokból úgy túnik, hogy a legfontosabb faktorok a Sportélvezet, mely a sportolás örömét fejezi ki, valamint az Értékes lehetőségek, amelyek azok a lehetőségek, amik csak a sport által élhetők meg. Ilyen lehet a mozgásélmény vagy a versenyzés, edzés élménye is (Scanlan, Russell, Scanlan, Klunchoo, \& Chow, 2013). A modell vizsgálja a sportolók személyes befektetéseit is (energia, idő és pénzbeli befektetések). A kutatók úgy látják, hogy aki szereti a sportágát, az többet is fektet bele, ám a befektetések kényszert is róhatnak az egyénre, mivel félő, hogy a befektetett energia elvész, ha a sport abbamarad (Scanlan et al., 2013). Ezért a kutatók kétféle megközelítésből vizsgálják a személyes befektetéseket. Egyfelól igyekeznek kideríteni, hogy egy adott sportoló mennyit fektet a sportágába (Személyes befektetések - mennyiség), és mennyire érzi kényszernek a sportágnál maradást, az addigi befektetett energia miatt (Személyes befektetések - veszteség). A modell számításba veszi a családtagoktól, barátoktól (Közösségi támogatás - érzelmi) valamint az edzőtől (Közösségi támogatás - informális) érkező támogatásokat is, és a szintén tőlük érkező elvárásokat (Közösségi kényszer). A vizsgálatok szerint a közösségi elvárások negatív kapcsolatban vannak a Lelkes elköteleződéssel, és pozitiv kapcsolatban az Erőltetett elköteleződéssel (Scanlan et al., 2016). Új elemként került be a modellbe a Törekvés 
a fejlődésre forrás, mely az egyéni teljesítésre, és mások legyőzésére irányulhat. Az Egyéb prioritások elem az Erőltetett elköteleződés legfőbb forrása, mely az egyéb tevékenységeket (pl. iskola, család, munka) veszi számításba.

Jelen kutatásunk célja megvizsgálni, hogy a sportolói identitás és a sport iránti elköteleződés között milyen kapcsolat áll fenn, hiszen a két modell segítségével talán jobban megérhetjük, milyen tényezők segítik, vagy gátolják a serdülőket sportolási szokásaik kialakulásában. Továbbá célunk feltárni a sportolói identitás szociodemográfiai változókkal (pl. nem, kor, tagozat) és sportolási szokásokkal (pl. edzésmennyiség, sportág, versenyzési szint) kapcsolatos összefüggéseit.

Hipotéziseinket a szakirodalommal összhangban állítottuk fel. Mivel számtalan kutatás bizonyította már, hogy a fiúk többet sportolnak és motiváltabbak (pl. Keresztes, Pluhár, \& Pikó, 2003) ezért feltételezzük, hogy a fuúk erőteljesebb sportolói identitással rendelkeznek, mint a lányok. A kutatások azt mutatják, hogy a sportolási kedv a kor előrehaladtával csökken (pl. Gál, Dóczi \& Sáringerné, 2012), így feltételezzük, hogy ez a jelenség a sportolói identitásban is megmutatkozik. A sportolói identitás hatással van a sportban való részvételre is (Lamont-Mills \& Christensen, 2006). Ezért feltételezzük, hogy az erősebb identitással rendelkező sportolók régebb óta sportolnak és versenyeznek, valamint többet is edzenek. Továbbá feltételezzük, hogy a sporttagozatos tanulók magasabb identitási indexszel rendelkeznek. Ong (2017) szerint minél magasabb szinten versenyez valaki, annál motiváltabb. Így azt gondoljuk, hogy fez hatással lehet a sportolói identitásra is, azaz a magasabb szinten versenyzőknél magasabb sportolói identitás-szinttel találkozhatunk. Annak ellenére, hogy kevés egyértelmű utalást találunk a szakirodalomban a sportágak motivációinak összehasonlítására, azt feltételezzük, hogy a sportolói identitás a csapatsportolóknál nagyobb mértékú lehet a "csapatszellem" és a közösség hajtóerejének köszönhetően (Stuntz \& Weiss, 2009). Még nem készült átfogó tanulmány a sport iránti elköteleződés és a sportolói identitás kapcsolatáról. Ugyanakkor korábbi kutatások a sportolói identitás és az öndeterminációs elmélet között legfőképp az identifikált és az integrált motiváció között találtak összefüggést (Vlachopoulos et al., 2011; Strachan et al., 2013). Ezért feltételezzük, hogy a sport iránti elköteleződés közösségi szintű változói, valamint a lelkes elköteleződés, a sportélvezet, a sportban rejlő lehetőségek, befektetések, az egyéni törekvé sek a fejlődésre, pozitív hatással lehetnek a sportolói identitásra, míg az alternatívák és az erőltetett elköteleződés inkább negatívan befolyásolhatja azt.

\section{Minta és módszerek}

Kutatásunkban 344 középiskolás sportoló (fiú $=131$, leány $=213$ ) vett részt, akiknek átlagéletkoruk 16,57 életév (szórás $=1,67$ ) volt. A résztvevő serdülő sportolók Budapest köznevelési típusú sportiskoláiból kerültek ki. A nyolc felkeresett középiskola közül négy vállalta, hogy részt vesz a kutatásunkban. A kérdőíves vizsgálatban részt vett serdülő sportolók több mint $80,9 \%$-a $(n=280)$ sporttagozatos osztályba járt, míg 19,1\% ( $n=64)$ a nem sporttagozatos osztályokat képviselte. A mintánkban szereplő sportolók átlagban 7,98 éve (szórás = 3,76) sportolnak, melyekből valamivel több, mint 5 éve versenyeznek is. A serdülő sportolók hetente átlagban 9,12 órát (szórás $=5,82$ ) töltenek edzéssel. A résztvevők különböző versenyzési szinteket képviselnek: válogatott szinten a résztvevők 16,5\%-a $(n=58)$ versenyez; országos versenyeken a mintának csaknem fele, azaz 45,7\%-a ( $n=158)$ vesz részt. Helyi szintú versenyzőket a kutatásban részvevők 16,6\%-a (n=61) képviseli. A hobbi szintű versenyzőket a minta 19,4\%-a $(n=67)$ teszi ki. Kutatásunkban összesen 42 sportág képviselői vettek részt. Az egyéni ( $n=183)$ és a csapat $(n=161)$ sportágak közel azonos arányban oszlanak meg. Budavári (2007) sportági csoportosítását használva megállapíthatjuk, hogy mintánk több mint fele a taktikai sportágakból került ki (n=176; pl. labdajátékok, tenisz) és 24,0\%-a valamilyen állóképességi sportágat úz ( $n=83$; pl. úszás, 
atlétika). A múvészeti sportágak képviselői mintánk 18,2\%-át adják ( $n=63$; pl. torna, tánc), és a résztvevők $5,2 \%$-a valamilyen küzdősportág versenyzője ( $n=18$; pl. karate, judo).

Az adatfelvételt önkitöltős kérdőíves módszerrel végeztük. Az intézményi etikai engedély megszerzését követően tájékoztattuk a résztvevő iskolák vezetését, tanárait, diákjait, valamint a kutatásban résztvevő diákok szüleit. Biztosítottuk őket arról, hogy semmilyen személyes adatot nem gyüjtünk, és válaszaikat kizárólag statisztikai adatelemzésre használjuk fel. A kérdőíveket a tanulók órai keretek között töltötték ki testnevelő tanárok felügyelete mellett. A kérdőív kitöltése kb. 25-30 percet vett igénybe.

Az összeállított kérdőívcsomagban szerepeltek a tanulók szociodemográfiai adataira vonatkozó kérdések (pl. nem, életkor, iskola típus), valamint sporttal kapcsolatos háttérinformációk (pl. Mit sportolsz? Heti hány órát töltesz edzéssel?).

A sportolói identitást az ún. Sportolói Identitás skála magyar változatával mértük (Brewer et al., 1993). A fordítást és az adaptációt mi magunk végeztük egy előző kutatásunkban (Berki \& Pikó, 2019). A skála 10 ite met tartalmazott, és a válaszokat egy 7 pontos Likert-típusú skálán lehetett megadni (1= egyáltalán nem értek egyet; 7= teljes mértékben egyetértek). A skála összpontszáma megadta az ún. Sportolói Identitás Indexet (770). Az index átlagértéke a mintánkon 47,20 volt. A skála megbízhatóságát vizsgáló Cronbach-alpha az egész mintán 0,95-es, azaz kiváló értéket mutatott. Az alminták megbízhatósága: a fiúknál 0,80, míg a lányoknál 0,94 volt. Az eredeti tanulmányban a teljes minta megbízhatósága 0,92 volt (Brewer et al., 1993).

A sport iránti elköteleződést a Scanlan és munkatársai (2016) által kidolgozott ún. „Sport-elköteleződés kérdőív-2" magyarra fordított és adaptált változatával mértük (Berki, Pikó \& Page, 2020). A skála összesen 52 itemből és 12 alskálából állt, és tartalmazta a kétféle elköteleződés típust (lelkes, erőltetett) és annak tíz forrását. Ezeket mi előzetes kutatásunk alapján egyéni szintű (Sportélvezet, Értékes lehetőségek, Egyéb prioritások, Személyes befektetések - veszteség, Személyes befektetések - mennyiség, törekvés a fejlődésre - képesség) és közösségi szintű (Közösségi nyomás, Közösségi támogatás - érzelmi, Közösségi támogatás - informális, Törekvés a fejlődésre - közösség) alskáláknak határoztuk meg (Berki, Pikó \& Page 2020). A válaszokat a résztve vőknek egy 5 -fokú Likert-típusú skálán ( 1 = egyáltalán nem értek egyet; 5 = teljes mértékben egyetértek) kellett megválaszolniuk. Az alskálák megbízhatósági mutatói 0,69 (közösségi támogatás-informális) és 0,92 (erőltetett elköteleződés) között változtak. A megbízhatósági értékek az eredeti tanulmányban 0,71 és 0,92 közöttiek voltak (Scanlan et al., 2016).

Az adatok feldolgozása SPSS statisztikai szoftverrel történt. Az elemzés során a leíró statisztikán túl a szociodemográfiai és a sport változók szerinti összehasonlítást kétmintás t-próbával, egyszempontos varianciaanalízissel végeztük, a változók erősségének mérésére Pearson-korrelációt használtunk. A sportolói identitás és a sport iránti elköteleződés kapcsolatát többváltozós lineáris regresszióval elemeztük, melyhez az ún. "stepwise" módszert alkalmaztuk.

\section{Eredmények}

Adataink elemzését a szociodemográfiai és a sporttal kapcsolatos változók vizsgálatával kezdtük. Először kétmintás t-próbával megvizsgáltuk, hogyan tér el a sportolói identitás nemenként, tagozatonként és az egyéni, valamint csapatsportolók között. Ezután egyszempontos varianciaanalízissel megvizsgáltuk a különbségeket versenyzési szintenként és sportágtípusonkként. Eredményeinket az 1. táblázat foglalja össze. Valamennyi vizsgált változó szignifikáns különbséget mutatott. 


\begin{tabular}{|c|c|c|c|}
\hline Kétmintás t-próba & & $\begin{array}{l}\text { Sportolói Identitás } \\
\text { (átlag, szóra) }\end{array}$ & t-érték \\
\hline \multirow{2}{*}{ Nem } & Fiú & $54,59(10,96)$ & \multirow{2}{*}{$6,93^{* * *}$} \\
\hline & Leány & $42,80(17,05)$ & \\
\hline \multirow{2}{*}{ Iskolai tagozat } & Sporttagozat & $49,60(15,04)$ & \multirow{2}{*}{$5,71^{* * *}$} \\
\hline & Nem sporttagozat & $36,13(16,38)$ & \\
\hline \multirow{2}{*}{$\begin{array}{l}\text { Egyéni / Csapat } \\
\text { sportolók }\end{array}$} & Egyéni sportolók & $42,06(16,86)$ & \multirow{2}{*}{$-6,56^{* * *}$} \\
\hline & Csapatsportolók & $53,00(13,03)$ & \\
\hline $\begin{array}{l}\text { Egyszempontos } \\
\text { varianciaanalizis }\end{array}$ & & $\begin{array}{l}\text { Sportolói Identitás } \\
\text { (átlag, szóra) }\end{array}$ & F-érték \\
\hline \multirow{4}{*}{ Versenyzés szintje } & Nemzetközi szint & $57,71(8,70)$ & \multirow{4}{*}{$117,37^{* * *}$} \\
\hline & Országos szint & $54,82(9,94)$ & \\
\hline & Helyi, megyei szint & $40,70(14,88)$ & \\
\hline & Hobbi szint & $26,79(11,71)$ & \\
\hline \multirow{4}{*}{ Sportágtípus } & Taktikai sportágak & $52,68(13,24)$ & \multirow{4}{*}{$21,84^{* * *}$} \\
\hline & Álóképességi sportágak & $44,82(17,36)$ & \\
\hline & Művészeti sportágak & $35,03(14,66)$ & \\
\hline & Küzdősportok & $44,00(17,40)$ & \\
\hline
\end{tabular}

1. táblázat: Sportoló identitás különbségei szociodemográfiai és sport változók mentén; ${ }^{* *} p<0,001$

A fiúk (átlag = 54,59) nagyobb fokú sportolói identitással rendelkeznek, mint a lányok (átlag $=42,80$ ), és a sporttagozatos diákok (átlag $=49,60$ ) is jelentősen magasabb pontszámot értek el, mint a nem sporttagozatos társaik (átlag = 36,13). Egyéni és a csapatsportolókat vizsgálva azt tapasztaltuk, hogy a csapatsportágak (átlag = 53,00) képviselőinek magasabb az identitásindexe, mint az egyéni sportágakat (átlag = 42,06) úzőké. Összehasonlítva a különböző versenyzési szintek képviselőit, azt tapasztalhatjuk, hogy minél magasabb szinten sportol valaki, annál magasabb lesz a sportolói önazonossága. Mintánkban a nemzetközi szinten versenyzők, azaz a válogatott sportolók érték el a legmagasabb pontszámot (átlag $=57,71$ ), mely folyamatosan csökken a versenyzési szint csökkenésével (hobbi sportolók átlag = 26,79). A sportágtípusoknál is jelentős eltérések találhatóak. A legmagasabb identitási indexet a taktikai sportágak képviselői érték el (átlag $=52,68$ ), ami nem meglepő, hiszen ők zömmel valamilyen csapatjátékot úznek. Az állóképességi (átlag $=44,82$ ) és a küzdősportágakban (átlag $=44,00$ ) sportolók hasonló értéket értek el, ám a múvészeti sportágak (átlag $=35,03$ ) képviselői átlag alatti identitással rendelkeznek a mintánkban.

Vizsgálatunk második részében megvizsgáltuk, hogy a kor, a sportban és versenyzésben eltöltött évek és az edzés mennyisége milyen kapcsolatban áll a sportolói identitással (2. táblázat). A serdülők sportolási szokásaira jellemző, hogy a kor előrehaladtával csökken a sportolási kedv. Ezt a mi eredményeink is igazolják, hiszen a sportolói identitás index $(r=-0,36)$, valamint a heti edzés mennyiség $(r=-0,20)$ a korral negatívan változik. Ugyanakkor a mintánkban szereplő serdülőknél pozitív kapcsolat mutatható ki a sportban eltöltött évek számával $(r=0,31)$, a versenyzésben eltöltött évek számával $(r=0,52)$ és a heti edzésmennyiséggel $(r=0,54)$. Így kijelenthetjük, hogy minél régebb óta sportol és versenyez valaki, annál többet fog edzeni, ami erőteljesebb sportolói identitáshoz vezethet. 
1

1. Sportolói

Identitás Index

1

2. Kor $-0,36^{* *} \quad 1$

3. Hány éve
sportolsz?

4. Hány éve sportolsz versenyszerüen?

5. Heti hány órát töltesz edzéssel?
$0,31^{* *} \quad 0,10$

$0,52^{* *} \quad 0,02$

$0,61^{* *}$

$0,22^{* *}$

$0,54^{* *}$

$-0,20^{* *}$

, $40^{* *}$

1

2. táblázat: Korrelációs kapcsolatok a sportolói identitás az életkor és sport változók között; ${ }^{* *} p<0,01$

Vizsgálatunk 3. részében arra voltunk kíváncsiak, hogy a sport iránti elköteleződés milyen változókon keresztül hat a sportolói identitásra. Ennek felderítésére ún. többváltozós lineáris regressziót alkalmaztunk "stepwise" módszerrel. A kapott eredményeink a végső modellt a variancia $78 \%$-ában magyarázták. Összesen kilenc változó került a modellbe. A Személyes befektetések-mennyiség $(\beta=0,25)$ és a Lelkes elköteleződés $(\beta=0,44)$ rendelkeznek a legnagyobb magyarázó erővel a sportolói identitásra. Az Értékes lehetőségek $(\beta=0,15)$, a Törekvés a fejlődésre - közösség $(\beta=0,18)$, az Erőltetett elköteleződés $(\beta=0,07)$ és a Közösségi támogatás - érzelmi $(\beta=0,08)$ változók szignifikánsan pozitív magyarázó erővel bírnak a modellben. Érdekes módon a Sportélvezet $(\beta=-0,10)$ és a Törekvés a fejlődésre - egyéni $(\beta=-0,11)$ szignifikánsan negativ magyarázó erőt mutatnak. A Közösségi kényszer $(\beta=0,06)$ ugyan bekerült a modellbe, de a végső változatban elveszítette a szignifikáns hatását. A Személyes befektetések - veszteség, Egyéb prioritások és a Közösségi támogatás - informális változók a regressziós módszer sajátosságai miatt kizárásra kerültek.

\begin{tabular}{|c|c|c|c|c|c|}
\hline & $\mathbf{F}$ & $\mathbf{R}^{2}$ & $\boldsymbol{\beta}$ & SE $\beta$ & t \\
\hline Step 1 & 533,70 & 0,62 & & & \\
\hline Személyes befektetések - mennyiségi & & & 13,80 & 0,78 & $23,10^{* * *}$ \\
\hline Step 2 & 384,80 & 0,70 & & & \\
\hline Személyes befektetések - mennyiségi & & & 8,37 & 0,47 & $10,75^{* * *}$ \\
\hline Lelkes elköteleződés & & & 6,67 & 0,42 & $9,28^{* * *}$ \\
\hline Step 3 & 296,60 & 0,73 & & & \\
\hline Személyes befektetések - mennyiségi & & & 6,06 & 0,35 & $7,28^{* * *}$ \\
\hline Lelkes elköteleződés & & & 4,98 & 0,32 & $6,88^{* * *}$ \\
\hline Értékes lehetőségek & & & 3,91 & 0,28 & $6,05^{* * *}$ \\
\hline
\end{tabular}




\begin{tabular}{|c|c|c|c|c|c|}
\hline Step 4 & 242,52 & 0,74 & & & \\
\hline Személyes befektetések - mennyiségi & & & 4,70 & 0,27 & $5,48^{* * *}$ \\
\hline Lelkes elköteleződés & & & 5,19 & 0,33 & $7,38^{* * *}$ \\
\hline Értékes lehetőségek & & & 3,27 & 0,24 & $5,11^{* * *}$ \\
\hline Közösségi kényszer & & & 2,29 & 0,17 & $4,72^{* * *}$ \\
\hline Step 5 & 204,80 & 0,75 & & & \\
\hline Személyes befektetések - mennyiségi & & & 4,94 & 0,28 & $5,86^{* * *}$ \\
\hline Lelkes elköteleződés & & & 6,28 & 0,40 & $8,41^{* * *}$ \\
\hline Értékes lehetőségek & & & 3,19 & 0,23 & $5,08^{* * *}$ \\
\hline Közösségi kényszer & & & 1,96 & 0,15 & $4,06^{* * *}$ \\
\hline Sportélvezet & & & $-3,36$ & $-0,12$ & $-3,78^{* * *}$ \\
\hline Step 6 & 180,53 & 0,76 & & & \\
\hline Személyes befektetések - mennyiségi & & & 4,05 & 0,23 & $4,73^{* * *}$ \\
\hline Lelkes elköteleződés & & & 5,91 & 0,37 & $8,01^{* * *}$ \\
\hline Értékes lehetőségek & & & 2,63 & 0,19 & $4,16^{* * *}$ \\
\hline Közösségi kényszer & & & 1,74 & 0,13 & $3,65^{* * *}$ \\
\hline Sportélvezet & & & $-3,63$ & $-0,13$ & $-4,16^{* * *}$ \\
\hline Törekvés a teljesítésre - közösség & & & 2,62 & 0,16 & $3,87^{* * *}$ \\
\hline Step 7 & 157,82 & 0,76 & & & \\
\hline Személyes befektetések - mennyiségi & & & 4,10 & 0,23 & $4,82^{* * *}$ \\
\hline Lelkes elköteleződés & & & 6,32 & 0,40 & $8,40^{* * *}$ \\
\hline Értékes lehetőségek & & & 2,46 & 0,18 & $3,89^{* * *}$ \\
\hline Közösségi kényszer & & & 1,31 & 0,10 & $2,60^{* * *}$ \\
\hline Sportélvezet & & & $-3,12$ & $-0,11$ & $-3,50^{* * *}$ \\
\hline Törekvés a teljesítésre - közösség & & & 2,65 & 0,16 & $3,94^{* * *}$ \\
\hline Erőltetett elköteleződés & & & 1,34 & 0,08 & $2,39^{* * *}$ \\
\hline Step 8 & 140,22 & 0,77 & & & \\
\hline Személyes befektetések - mennyiségi & & & 3,77 & 0,22 & $4,40^{* * *}$ \\
\hline Lelkes elköteleződés & & & 6,33 & 0,40 & $8,46^{* * *}$ \\
\hline Értékes lehetőségek & & & 2,27 & 0,16 & $3,58^{* * *}$ \\
\hline Közösségi kényszer & & & 1,10 & 0,08 & $2,15^{*}$ \\
\hline Sportélvezet & & & $-3,00$ & $-0,11$ & $-3,38^{* * *}$ \\
\hline Törekvés a teljesítésre - közösség & & & 2,52 & 0,15 & $3,76^{* * *}$ \\
\hline Erőltetett elköteleződés & & & 1,54 & 0,09 & $2,73^{*}$ \\
\hline
\end{tabular}




\begin{tabular}{|c|c|c|c|c|c|}
\hline Közösségi támogatás - érzelmi & & & 1,05 & 0,07 & $2,15^{* *}$ \\
\hline Step 9 & 129,07 & 0,78 & & & \\
\hline Személyes befektetések - mennyiségi & & & 4,38 & 0,25 & $4,92^{* * *}$ \\
\hline Lelkes elköteleződés & & & 7,04 & 0,44 & $8,78^{* * *}$ \\
\hline Értékes lehetőségek & & & 2,20 & 0,15 & $3,49^{* *}$ \\
\hline Közösségi kényszer & & & 0,86 & 0,06 & 1,67 \\
\hline Sportélvezet & & & $-2,71$ & $-0,10$ & $-3,11^{* * *}$ \\
\hline Törekvés a teljesítésre - közösség & & & 2,99 & 0,18 & $4,31^{* * *}$ \\
\hline Erőltetett elköteleződés & & & 1,36 & 0,07 & $2,39^{* * *}$ \\
\hline Közösségi támogatás - érzelmi & & & 1,27 & 0,08 & $2,59^{*}$ \\
\hline Törekvés a teljesítésre - egyéni & & & $-2,27$ & $-0,11$ & $-2,37^{* *}$ \\
\hline
\end{tabular}

\section{Következtetések}

Kutatásunk fókuszában a serdülő sportolók ún. sportolói identitásának a vizsgálata állt. Jelen tanulmányban ezt a kérdést egyfelől a szociodemográfiai változókkal és sportolási szokásokkal kapcsolatos változók felől közelítettük meg, másfelől megvizsgáltuk a sportolói identitás és a sport iránti elköteleződés kapcsolatát. A szociodemográfiai változókkal és sportolási szokásokkal kapcsolatos elemzések a nemzetközi szakirodalommal megegyező eredményeket hoztak, ugyanakkor a két modell összehasonlításának nemzetközi kontextusba helyezésére nem volt mód, mivel eddig nem készült átfogó előzetes tanulmány.

Köztudott, hogy a fiúk többet sportolnak és motiváltabbak, mint a lányok (Keresztes et al., 2003), valamint a kor előrehaladtával csökken a sportolási kedv (Gál, Dóczi \& Sáringerné, 2012). Úgy tűnik nincs ez másképp a sportolói identitás terén sem, hiszen a fiúknál jelentősen magasabb értéket találtunk, mint a lányoknál, és a kor is negatívan korrelált a sportolói identitás indexszel.

Korábbi vizsgálatainknál (Berki \& Pikó, 2018) - amelyek a sport iránti elköteleződésről szóltak - azt tapasztaltuk, hogy aki magasabb szinten köteleződik el a sportága iránt, régebb óta sportol, több időt fektet sportágába, és magasabb szinten is úzi azt, mint a kevésbé elkötelezettek. Ez azzal magyarázható, hogy az elköteleződés nemcsak a sportág szeretetéből fakadhat, hanem az eredmények és a befektetett energia is hatással le het a sportolóra (Berki \& Pikó, 2018). Ez a megfigyelés igaz ezen kutatás eredményeire is. A versenyzési szinttel nőtt az identitás-index mértéke is, és korrelációs elemzésünk is ezt a tézist igazolta, hiszen a sportban és a versenyzésben eltöltött évek, valamint az edzésmennyiség is pozitívan korrelálnak a sportolói identitás indexszel. Azaz minél régebb óta sportol valaki, annál többet fektet bele, így erősebb lesz az identitása is.

Beigazolódott a sporttagozatos diákokra felálított hipotézisünk is. Ők erősebb sportolói identitással rendelkeznek, ám ez nem meglepő, hiszen közülük kerültek ki azok a sportolók, akik magasabb szinten versenyeznek, és többet edzenek, mint a nem sporttagozatos serdülók. A sportági típusok összehasonlítását a szakirodalom óvatosan kezeli, hiszen a vizsgálatok igen széles skálán mozgó eredményekről számolnak be (pl. Mikulán \& Pikó, 2012; Jakobsen, 2014). Tanulmányunkban a csapatsportágak képviselői rendelkeznek a legnagyobb mértékú identitással (mindkét csoportosítás szerint). Ennek okát abban látjuk, hogy a csapatsportágakban a közösségnek és a csapatkohéziónak köszönhetően a sportolók jobban tudnak kötődni saját sportágukhoz és csa- 
pattársaikhoz, így kialakítva az erősebb identitást. Az önazonosságot az is növelheti, hogy a csapatsportágat űző sportolók egymást biztatva egymásért is sportolnak, növelve a sportág iránti szeretetet (Mikulán \& Pikó, 2012). Fontos megjegyezni, hogy a korábbi identitást és az öndeterminációt vizsgáló tanulmányok erős korrelációt találtak a sportolói identitás és az identifikáció, valamint az integráció között. Az identifikált és az integrált szabályozási formák alapvetően az extrinzik motivációhoz tartoznak, ugyanakkor tartalmazhatnak intrinzik elemeket is (Deci \& Ryan, 2000). Ezek az elemek valamilyen belső indíttatásra (pl. lelkiismeret) vagy célokra utalhatnak, melyek kapcsolatban állhatnak a sportolói identitással is.

Kutatásunk második részében arra voltunk kíváncsiak, milyen kapcsolat található a sportolói identitás és a sport iránti elköteleződés között. A legjobb tudomásunk szerint ilyen jellegú kutatás még nem készült. A „stepwise" többváltozós regresszió elemzés számos meglepő eredményt hozott. A sportolói identitást a Személyes befektetések - mennyiség és a Lelkes elköteleződés magyarázzák a legnagyobb mértékben. Szerintünk ezt az eredményt legjobban maga a sportolói identitás fogalma magyarázza. Hiszen ez a fogalom a sportolói szerep köré épül, amelyet a sport iránti vágy (Lelkes elköteleződés), valamint annak mértéke táplál, amit a Személyes befektetések - mennyiség képvisel (Brewer et al., 1993). Azaz a magas fokú sportolói identitás kialakulásához fontos a sport iránti vágy, és hogy a sportoló minél többet fektessen a sportágába.

Az Értékes lehetőségek, Törekvés a fejlődésre - közösség, Közösségi támogatás - érzelmi és az Eröltetett elköteleződés is közel azonos pozitív magyarázó erővel rendelkezett. Úgy gondoljuk, hogy a lehetőségek fontos részét képezhetik a sportolók identitásának, hiszen a sportolók ragaszkodása egy-egy versenyhez, helyszínhez vagy tevékenységhez növelheti önazonosságukat. A közösségi szintú változók arányát úgy gondoljuk, hogy az identitás jellege adja, hiszen mintánkban a csapatsportágak szerepének is nagy volt a jelentősége. Ez a sportolói közösség identitásformáló erejét igazolja. Ebben az eredményben is közrejátszhatott, hogy a már említett öndeterminációs elmélet is kiemeli az extrinzik elemekkel való kapcsolatot (Vlachopoulos et al., 2011; Strachan et al., 2013).

Az Erőltetett elköteleződés előzetes feltételezéseinktől eltérően pozitiv magyarázó erőként jelenik meg a végső modellben. A korábbi kutatások ezt a faktort inkább a sportot gátló és arra ható kötelezettségeként írták le (Scanlan et al., 2016). Ez az eredmény arra enged következtetni, hogy a sportolói identitást nemcsak a belső indíttatás táplálja, hanem a külső motiváció és a kényszer is megjelenhet a sportolók identitásának formálásában, vagyis azok a sportolók, akik magas fokú identitással rendelkeznek, nem feltétlenül a sport szeretete és annak vágya miatt sportolnak. Előfordul, hogy kényszer és kötelességtudat alakítja az identitást, hiszen maga sabb versenyzési szinteken ezek is késztetést jelenthetnek a további versenyzéshez (Chantal, Guay, DobrevaMartinova, Vallerand, 1996; Scanlan Russell, Magyar, Scanlan, 2009).

További nem várt eredménye a vizsgálatnak, hogy a Sportélvezet és a Törekvés a fejlődére - egyéni negativ magyarázó erővel rendelkeznek. Mindez eltérést mutat a szakirodalomtól, ahol mind a két elem a sportmotivációt és az elköteleződést pozitivan erősítő elemként szerepel (Scanlan et al., 1993, 2016). Jelen kutatásban azonban úgy túnik, hogy az örömnek és az egyéni fejlődésnek a sportban nincs akkora jelentősége a sportolói identitás formálódásában. Utóbbi elem negatív eredménye talán azzal magyarázható, hogy a Törekvés a fejlő désre - közösségi változóval ellentétet alkothat, de sajnos erre nagyon kevés információval rendelkezik a szakirodalom (Scanlan et al., 2016). Úgy gondoljuk, hogy a Sportélvezet és a Törekvés a fejlődésre - egyéni ilyen jellegű eredménye azt mutathatja, hogy a sportolás örömének és az egyéni fejlődésnek a mértéke önmagában cél, és nincs nagy hatással a sportolók identitásra.

Összefoglalásként elmondhatjuk, hogy a sportolói identitásra hatással vannak a szociodemográfiai adatok és a sportolási szokások. A különböző sportmotivációs tanulmányoknál (Vlachopoulos et al., 2011; Strachan et 
al., 2013) és az előzetesen felállított hipotéziseinkkel megegyezően, a sportolói identitás szintje különbözik nemenként, tagozatonként, versenyzési szintekként és függ a kortól, a sportágban eltöltött időtől és az edzésmennyiségtől is. A sportolói identitás és a sport iránti elköteleződés közötti összefüggések eredményei csupán részben igazolódtak, hiszen a Sportélvezet és a Törekvés a fejlődésre - egyéni faktorok (melyek nagymérték ben kapcsolódnak a belső motivációhoz) negatív kapcsolatban állnak az identitással. Az identitás kapcsolata az Erőltetett elköteleződéssel is érdekes eredményt mutatott, hiszen pozitív magyarázó ereje arra enged következtetni, hogy a kényszerből sportolóknál is magas lehet a sportolói identitás. Előzetes hipotéziseinkkel megegyezően a Lelkes elköteleződés, az Értékes lehetőségek és a Személyes befektetések - mennyiség mind pozitív kapcsolatban állnak a sportolói identitással.

Jelen tanulmánnyal igyekeztünk átfogó képet adni a sportolói identitásról, de a kutatás számos korláttal is rendelkezett. Elsősorban a mintavételi eljárás sajátossága miatt a nemek aránya jelentősen eltolódott a lányok javára. Valamint az összehasonlítások jobb megbízhatósága érdekében magasabb elemszámra lett volna szükség. Úgy gondoljuk, hogy a jövőben ezeket mindenképp fejlesztenünk kell, és kibővíteni a kutatást. Érdekes le hetne például összehasonlítani a nem sportoló és a sportoló diákok identitását, hiszen úgy látjuk, hogy az identitás jobban mérhető a nem sportoló diákok körében, mint a sportmotiváció. Hisszük, hogy a sportolói identitással átfogóbb képet kaphatunk a serdülők sportolási szokásairól, ami segíthet a pedagógusoknak, a kutatóknak, a pszichológusoknak és a sportszakembereknek megelőzni a sportági lemorzsolódást.

\section{Irodalom}

1. Berki, T., \& Pikó, B. (2019). A magyar változatú sportolói identitásskála faktorszerkezetének feltárása szociodemográfiai adatok mentén. In. Molnár, E. K. \& Dancs, K. (eds.) XVII. Pedagógiai Értékelési Konferencia. Szeged, 21.

2. Berki, T., \& Pikó, B. (2018). A sport iránti elköteleződés összefüggése a sportolási szokásokkal és demográfiai tényezőkkel serdülő sportolók körében. In. Hamar, P. \& Köpf, K. (eds.). Mozgás - biológia sport - tudomány, (pp. 170-180). Budapest: Magyar Edzők Társasága.

3. Berki, T., Pikó, B. F., \& Page, R. M. (2020). Hungarian adaptation of the sport commitment questionnaire-2 and test of an expanded model with psychological variables. Physical Culture and Sport. Studies and Research, 86(1), 15-26. DOI: 10.2478/pcssr-2020-0009

4. Budavári, Á. (2007). Sportpszichológia. Budapest: Medicina Könyvkiadó Zrt.

5. Baker, C. W., Little, T. D., \& Brownell, K. D. (2003). Predicting adolescent eating and activity behaviors: The role of social norms and personal agency. Health Psychology, 22(2), 189-198. DOI: 10.1037//0278-6133.22.2.189

6. Brewer, B. W., Van Raalte, J. L., \& Linder, D. E. (1993). Athletic identity: Hercules' muscles or Achilles' heel? International Journal of Sport Pychology, 24, 237-254.

7. Burns, G. N., Jasinski, D., Dunn, S. C., \& Fletcher, D. (2012). Athlete identity and athlete satisfaction: The nonconformity of exclusivity. Personality and Individual Differences, 52(3), 280-284. DOI: 10.1016/j.paid.2011.10.020

8. Chantal, Y., Guay, F., Dobreva-Martinova, T., Vallerand, R.J. (1996). Motivation and elite . performance: an exploratory investigation with Bulgarian athletes. International Journal of Sport Psychology, 11(2), 173-182.

9. Deci, E. L., \& Ryan, R. M. (2000). The "what" and "why" of goal pursuits: Human needs and the selfdetermination of behavior. Psychological Inquiry, 11(4), 227-268. DOI:

10.1207/s15327965pli1104_01 
10. Deephouse, D. L., \& Jaskiewicz, P. (2013). Do Family Firms Have Better Reputations Than Non-Family Firms? An Integration of Socioemotional Wealth and Social Identity Theories. Journal of Management Studies, 50(3), 337-360.

11. Gál, A., Dóczi, T. \& Sáringerné, Sz., Zs. (2012). Társadalmi befogadás a sportban és a sport által. (szociális inklúzió), Budapest: Magyar Sportmenedzsment Társaság, 113.

12. Jakobsen, A. M. (2014). Are there differences in motives between participants in individual sports compared to team sports? LASE Journal of Sport Science, 5(2), 30-40. DOI: 10.1515/ljss-2016-0030

13. Keresztes, N., Pluhár, Zs., \& Pikó, B. (2003). A fizikai aktivitás gyakorisága és sportolási szokások általános iskolások körében. Magyar Sporttudományi Szemle, (4), 43-47.

14. Lamont-Mills, A., \& Christensen, S. A. (2006). Athletic identity and its relationship to sport participation levels. Journal of Science and Medicine in Sport, 9(6), 472-478. DOI: 10.1016/j.jsams.2006.04.004

15. Martin, L. A., Fogarty, G. J., \& Albion, M. J. (2013). Changes in athletic identity and life satisfaction of elite athletes as a function of retirement status. Journal of Applied Sport Psychology, 26(1), 96-110. DOI: $10.1080 / 10413200.2013 .798371$

16. Mikulán, R. (2007). Serdülőkorú versenysportolók egészségének és egészségmagatartásának vizsgálata. Magyar Sporttudományi Szemle, 8(30), 8-11.

17. Mikulán, R., \& Pikó, B. (2012). Iskoláskorú sportoló fiatalok káros szenvedélyeinek vizsgálata a sportmotivációik és a sportág típusa tükrében. Iskolakultúra, 4, 35-50.

18. Ong, N. C. (2017). Assessing objective achievement motivation in elite athletes: A comparison according to gender, sport type, and competitive level. International Journal of Sport and Exercise Psychology, 17(4) 397-409. DOI: 10.1080/1612197x.2017.1349822

19. Pataki, F. (1982). Az én és a társadalmi azonosságtudat. Budapest: Kossuth.

20. Scanlan, T. K., Carpenter, P. J., Simons, J. P., Schmidt, G. W., \& Keeler, B. (1993). An Introduction to the Sport Commitment Model. Journal of Sport and Exercise Psychology, 15(1), 1-15. DOI: 10.1123/jsep.15.1.1

21. Scanlan, T. K., Chow, G. M., Sousa, C., Scanlan, L. A., \& Knifsend, C. A. (2016). The development of the Sport Commitment Questionnaire-2 (English version). Psychology of Sport and Exercise, 22, 233-246. DOI: 10.1016/j.psychsport.2015.08.002

22. Scanlan, T. K., Russell, D. G., Magyar, T. M. \& Scanlan, L. A. (2009): Project on Elite Athlete Commitment (PEAK): III. An examination of the external validity across gender, and the expansion and clarification of the Sport Commitment Model. Journal of Sport \& Exercise Psychology, 31(6), 685-705. DOI: $10.1123 /$ jsep.31.6.685

23. Scanlan, T. K., Russell, D. G., Scanlan, L. A., Klunchoo, T. J., \& Chow, G. M. (2013). Project on Elite Athlete Commitment (PEAK): IV. Identification of new candidate commitment sources in the Sport Commitment Model. Journal of Sport and Exercise Psychology, 35(5), 525-535. DOI: 10.1123/jsep.35.5.525

24. Stuntz, C. P., \& Weiss, M. R. (2009). Achievement goal orientations and motivational outcomes in youth sport: The role of social orientations. Psychology of Sport and Exercise, 10(2), 255-262. DOI: 10.1016/j.psychsport.2008.09.001

25. Strachan, S. M., Fortier, M. S., Perras, M. G., \& Lugg, C. (2013). Understanding variations in exerciseidentity strength through identity theory and self-determination theory. International Journal of Sport and Exercise Psychology, 11(3), 273-285. DOI: 10.1080/1612197x.2013.749005

26. Szabó, A. (2018). Addiction, passion, or confusion? New theoretical insights on exercise addiction research from the case study of a female body builder. European Journal of Psychology, 14(2), 296-316.

27. Tekman, H. G., \& Hortaçsu, N. (2002). Music and social identity: Stylistic identification as a response to musical style. International Journal of Psychology, 37(5), 277-285. DOI: $10.1080 / 00207590244000043$ 
28. Van Dusen, D. P., Kelder, S. H., Kohl, H. W., Ranjit, N., \& Perry, C. L. (2011). Associations of physical fitness and academic performance among schoolchildren. Journal of School Health, 81(12), 733-740. DOI: $10.1111 / \mathrm{j} .1746-1561.2011 .00652 . x$

29. Vlachopoulos, S. P., Kaperoni, M., \& Moustaka, F. C. (2011). The relationship of self-determination theory variables to exercise identity. Psychology of Sport and Exercise, 12(3), 265-272. DOI: 10.1016/j.psychsport.2010.11.006

30. Weisz, C., \& Wood, L. F. (2005). Social identity support and friendship outcomes: A longitudinal study predicting who will be friends and best friends 4 years later. Journal of Social and Personal Relationships, 22(3), 416-432. DOI: 10.1177/0265407505052444

31. Wilson, P. M., \& Muon, S. (2008). Psychometric properties of the exercise identity scale in a university sample. International Journal of Sport and Exercise Psychology, 6(2), 115-131. DOI: 10.1080/1612197x.2008.9671857

\section{The Significance of Athletic Identity in Sport Education: its Relationship with Sport Commitment among Adolescent Athletes}

Several international studies showed the importance of athletic identity among athletes since it may indirectly influence adolescent mental and physical development. There are only a few studies investigating athlete's identity in Hungary, therefore our goal was to explore the relationships between athletic identity with sociodemographics, sport participation and sport commitment. Participants were 344 adolescent athletes with the age of 16.6 and they completed questionnaires about sociodemographics, sport participation athletic identity and sport commitment. Independent sample t-tests, ANOVA, Pearson correlation, and regression analysis were used to analyze our data. In our results, we found that the level of athletic identity differed according to gender, school type, level of competition, and depends on age, time in sport, and the amount of training. Our regression analysis showed that sport commitment had a great role in athletic identity. The Personal Investment - quantity and Enthusiastic Commitment had the greatest impact on the athlete's identity. Valuable Opportunities, Desire to - Excel - social, Constrained Commitment and Social Support emotional had a positive significant connection with identity as well. Interestingly, Sport Enjoyment, Desire to Excel - mastery had negative effects on athletic identity, while previous studies highlighted their positive impact on physical activity. We might conclude that, besides internal motivation social impact and constrained reasons of sport participation could influence the athletic identity.

Keywords: athletic identity, sport commitment, adolescent, regression 